\title{
Community Colleges and Local Universities in Response to Manpower Development Demands in Viet Nam*
}

\author{
Dang Ba Lam \\ National Institute of Educational Management, Ha Noi, Viet Nam; \\ Vietnam Institute for Education Sciences, Ha Noi, Viet Nam; \\ Association of Vietnamese Universities \& Colleges, Ha Noi, Viet Nam \\ Tran Thi Thai Ha, Dinh Thi Bich Loan \\ Viet Nam Institute for Education Sciences, Ha Noi, Viet Nam
}

\begin{abstract}
The cause of industrialisation and modernization in Viet Nam, especially in the light of international integration, economic globalisation, and high-tech working environments, has posed crucial requirements for highly-skilled workers. Manpower training and development is becoming one of the most significant missions of higher education. The model of community college and local university in Viet Nam has made an important contribution to realizing this mission. In this context, the paper has presented a status quo of manpower development and labour force in Viet Nam, and provided information on the establishment and development of community colleges and local universities - a type of community higher education institutions in Viet Nam. In addition, the paper has shared key survey findings in response to the local manpower demands among typical community colleges and local universities, hence contributing to shedding light on efficiencies and shortcomings these institutions facing in the realization of the above-said mission.
\end{abstract}

Keywords: community college, local university, manpower training, industrialization

\section{Industrialisation in Viet Nam and Its Requirements for Manpower Development}

In the history of the world's development, dated back several centuries, the countries in Western Europe carried out their industrialization by accumulating domestic labour and exploiting both domestic and overseas resources. At the beginning of the 20th century, when the socialist camp was in existence, a number of under-developed countries, including Viet Nam, wished to progress to socialism without going through capitalism stage. Such countries carried out their industrialization with the help of the Soviet Union - the first state in the world to be based on Marxist socialism. The course of socialist industrialization in the Soviet Union required that the priority be placed on the development of heavy industries, with the belief in the central importance of electrification to the achievement of communism (this belief was represented by Lenin's statement: Communism was Soviet power plus the electrification of the whole country).

\footnotetext{
*Acknowledgement: This paper is a product of the research project with the code VI 2.3-2012.2013 funded by National Foundation for Science and Technology Development (NAFOSTED).

Dang Ba Lam, Ph.D., associate professor, National Institute of Educational Management; Vietnam Institute for Education Sciences; Association of Vietnamese Universities \& Colleges.

Tran Thi Thai Ha, Ph.D., associate professor, Viet Nam Institute for Educational Sciences.

Dinh Thi Bich Loan, MA., senior researcher, Viet Nam Institute for Educational Sciences.
} 
However, Viet Nam mapped out the strategic plans for economic development and initiated its industrialization in 1961 (The Communist Party of Vietnam, 1961), several years after which the war occurred in the country. After the war ended, the crisis and collapse of Soviet Union and the demise of socialist regimes did not allow Viet Nam to keep following that path.

Currently, Viet Nam is carrying out its industrialization in the context of well-developed science and technology and strengthened globalization. It has taken lessons and experience from newly-developed countries, so that it would not take the same industrialization path as that taken by previous states, and it can make best use of the latest science and technology achievements in order to rapidly industrialise the country based on quality manpower. Viet Nam set the target of achieving industrialized country status by 2020 (The Communist Party of Vietnam, 1991).

In fact, since the launch of Doi Moi (Renovation) in 1986, Viet Nam has earned gradually high and stable economic growth rates on a year-over-year basis. Since 2007, when Viet Nam was officially recognised as the member of the World Trade Organisation, the export turnover and attraction of foreign direct investment (FDI) have been recorded high, whilst the attention paid by foreign businesses to Viet Nam has become increasingly high with the arrival of many sizable investors, along with various investment on projects in high-tech industries ranging from hundreds of million to billions of dollars.

However, the economic growth of Viet Nam is mainly based on the export of raw or crudely-processed materials; or simply by participating in the fabrication and assembly phases which yields low-added value as well as trivial export value. The ability to own and develop technology still remains limited; the machinery and production materials are by large import; the obsolete technology is applied, leading to low productivity. One of the causes leading to this scenario lies in the limited capacity in manpower.

The statistical data below indicate that the share of trained labour force in Viet Nam still remains very low (see Table 1). As of the fourth quarter of 2015, Viet Nam had a total of 54.59 million people aged 15 or higher falling in the labour force, of which more than 43.55 million people (accounting for $79.78 \%$ of the total labour force) have never received any training to obtain a certificate or degree of any kind (a decrease of $2 \%$ as against 2013). Of the labour force that has received training, those with university qualifications or higher account for the highest share (more than 40\%) and concentrate mainly in urban areas (more than $70 \%$ ).

Table 1

Labour Force by Professional and Technical Qualifications in 2015 (Unit: 1,000 People)

\begin{tabular}{|c|c|c|c|c|}
\hline No & & Nationwide & Urban & Rural \\
\hline & Total workforce & $54,590.7$ & $17,449.1$ & $37,141.6$ \\
\hline & Without professional and technical trainings & $43,556.6$ & $11,144.9$ & $32,411.6$ \\
\hline & With training degrees/qualifications & $11,024.7$ & $6,303.8$ & $4,720.9$ \\
\hline & \multicolumn{4}{|l|}{ Of which: } \\
\hline & Three-month vocational training & $2,571.9$ & $1,211.6$ & $1,360.4$ \\
\hline & Professional secondary education & $2,138.4$ & 982.9 & $1,155.5$ \\
\hline & Professional college & $1,475.9$ & 713.6 & 762.2 \\
\hline & University or higher & $4,838.5$ & $3,395.7$ & $1,442.8$ \\
\hline & Not defined & 9.4 & 0.4 & 9.0 \\
\hline
\end{tabular}

Note. Labour force and employment survey report, 4th quarter 2015, GSO.

Also, according to the 2015 statistics, of the total 53.5 million people who are currently employed across the country, more than two-thirds are working in rural areas; only more than 10.6 million people, or $19.89 \%$ of 
total employed labour force, have received professional and technical training (see Table 2).

Table 2

The Percentage of Employed Labour Force That Has Received Training/Qualifications, 2015 (Unit: \%)

\begin{tabular}{llcc}
\hline & Nationwide & Urban & Rural \\
\hline Total of which: & 19.89 & 37.14 & 12.64 \\
Three-month vocational training & 4.72 & 7.23 & 3.71 \\
Professional secondary education & 3.88 & 5.80 & 3.12 \\
Professional college & 2.54 & 3.98 & 1.96 \\
University or higher & 8.75 & 20.13 & 3.84 \\
\hline
\end{tabular}

Note. Labour force and employment survey report, 4th quarter 2015, GSO.

It can be seen from Table 2 that the quality of manpower in Viet Nam remains low and uneven among regions, with the rural area significantly lower than in urban area.

According to the 2014 White Book of Trade/Investment Issues and Recommendations published by European Chamber of Commerce in Vietnam (EuroCham) ${ }^{1}$ on business and investment environments in Viet Nam in 2013, it clearly stated, "In Association of the South-East Asia Nations (ASEAN) bloc, Viet Nam lies at the bottom half of the ranking on manpower development. Therefore, developing and strengthening skills for the labour force is one of the crucial tasks of Viet Nam in order to meet the demands of the rapidly changing labour market." This remark is similar to that made by International Labour Organisation (ILO) on labour productivity in Viet Nam, which is among the lowest levels in the Asia-Pacific region. Labour productivity in Singapore in 2013 was nearly 15 times, Japan 11 times, and South Korea 10 times, the level of Viet Nam. Even compared to Malaysia and Thailand - two other middle-income ASEAN countries, Viet Nam's productivity were only one-fifth and two-fifths respectively in 2013. A remarkable trend is that the growth rate of labour productivity has declined in Viet $\mathrm{Nam}^{2}$. In a research project commissioned by the World Bank, it stated that increasing the share of workers with university qualifications was a critical requirement for Viet Nam (Word Bank, 2008).

The above analyses have shown that the quality of manpower remains a significant barrier for the socio-economic development of Viet Nam, especially in rural areas. On the other hand, national universities undertake very slow changes and therefore fail to meet immediate and timely manpower demands of provinces and cities. Against this context, developing community colleges and local universities may be a solution to address this shortcoming.

\section{Community Colleges and Local Universities in the Course of Manpower Development in Viet Nam}

\section{Community Colleges in Viet Nam}

The concept of community education has been used since the late 19th century in the United States of America and Canada to refer to short-term training courses that met the demands of increasing knowledge, understanding, and skills for improving the production processes of the local community, without regard to age, race, income, social structure... Thereafter, the concept was used in Europe. In Viet Nam, it was used from early on in the South, although in the North there had been some types of community education in existence.

With regard to community college, several researchers (Dang, 1996; Nguyen., 2009; Nguyen 2011; Dang \&

\footnotetext{
${ }^{1}$ Retrieved from http://mku.edu.vn/khoacntt/index.php/tin-t-c/71-sach-tr-ng-bao-d-ng-d-v-nhan-l-c-vi-t-nam.

2 Retrieved form http://www.molisa.gov.vn/vi/Pages/chitiettin.aspx?IDNews=21153.
} 
Nguyen, 2009) have drawn the following key characteristics of this type of educational institution:

1. It is the one owned by the community, decided by the community and serving the interests of the community. The term "community" in this case is understood as a small residential area within a larger community. In the United States of America, it is the college owned by State. In Canada, it is the college belonging to the provincial authority. The community college caters to the diverse pre-service and in-service training demands of the community at the collegiate level or lower, mobilises resources from community (i.e., both local government and residents), and involves community members' active participation in the college administration;

2. Members of the local community enjoy certain priorities when enrolled to study in the local community college compared against outside residents, including, for example, the preferential treatment over the entrance examinations, waiver or reduction of tuition fees;

3. Training programmes provided by community colleges are very diverse, with the following key types (see Figure 1):

(a) Associate programmes (two years) to allow students to transfer to universities which entered into an agreement with the community college. This programme is very popular in the United States of America and takes up a large portion of students in community colleges. However, when this type of programme is applied in other countries in which the transfer is not as easy as in the United States of America, the role of these associate programmes becomes very small or even non-existent, as least not as big as that in the United States of America.

(b) The professional training programme (three years). This programme provides training on practical and professional skills leading to the awarding of an advanced diploma, similar to the college degree in Germany or Technical and Further Education (TAFE) in Australia, or referred to as "college training diploma" in Viet Nam in accordance with its Education Law 1998.

(c) Training programmes of very diverse natures in duration (i.e., a couple of days, weeks, or even months) and content (vocational training, life skills, cultural integration, community integration ...).

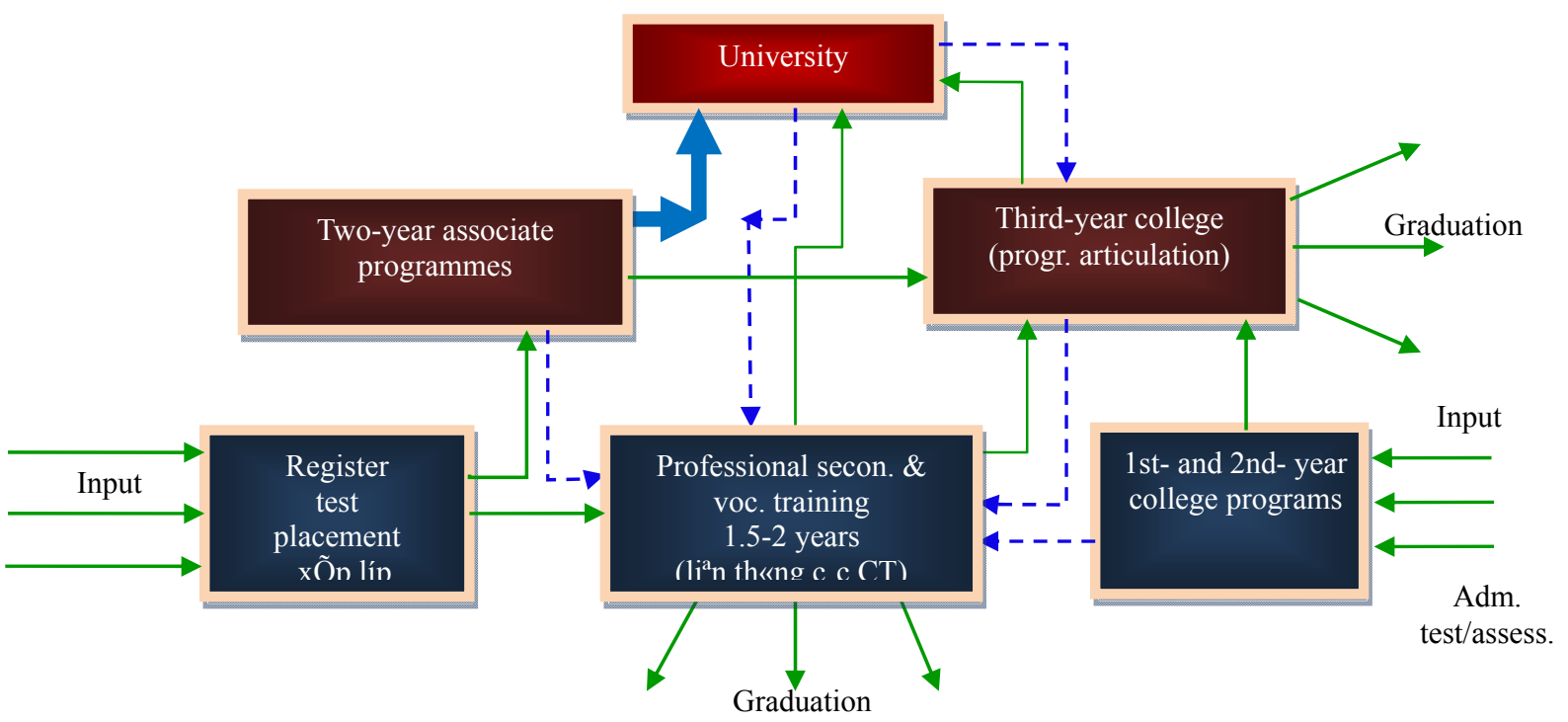

Figure 1. The model for transfer and articulation training in community colleges (Source: Nguyen, 2009).

Notes:(1) training transfer.

(2) $\longrightarrow$ upward articulation training.

(3) $---\rightarrow$ downward articulation training.

(4) Articulation of programmes within the same level of professional secondary, vocational education, or college education. 
As it can be seen, in terms of training level, unlike universities, community colleges do not provide complete training or award degrees at the university level. That is why they are all called college (community college, formerly junior college). According to the Education Law and Law on Higher Education of Viet Nam, these are referred to as "colleges."

In Viet Nam, community colleges are public-run education institutions invested and run by local government to meet diverse manpower demands of local community. They have the legal status just like any other type of college within national education system. They provide multi-level training (at collegiate level or lower), inter-disciplinary programmes which are articulated among various training levels in many different forms. In addition, they link their trainings with the utilization of manpower in the labour market, establishing a very close relationship with production units, especially in providing support to local small- and medium- sized farms or factories specializing in cultivation, breeding, agriculture fishery, and forestry processing.

In 1971, when Viet Nam was split into two regions, North and South, in the South of Viet Nam, the community college was established by the name of "Community University," with three Community Universities, namely, Tien Giang (established in 1971), Nha Trang (established in 1971), and Da Nang (established in 1973), having missions similar to that of community colleges in the United States of America.

Following the country's reunification, the community college model was subjected to reinvestigation as from the Economic Renovation (1986). In 1996, Asia Development Bank (ADB) provided financial support to the Research Institute of Professional and Higher Education through a research project that piloted the community college model in five provinces/cities: Ha Tay, Hai Phong, Thanh Hoa, Phu Yen, and Dong Thap.

Following the research projects and pilots, with the support of the Governments of Netherlands, Canada, and France, the Directive of the Government of Viet Nam was issued on developing the community college model, by virtue of which the first five community colleges were established across three regions: North, Middle, and South - Hai Phong, Quang Ngai, Ba Ria-Vung Tau, Tien Giang, and Dong Thap. Later, a number of other community colleges were established in other provinces, i.e., Ha Tay and Tra Vinh in 2001; Kien Giang and Vinh Long in 2002; Ha Noi, Hau Giang, and Soc Trang in 2006; and Ca Mau and Binh Thuan in 2007. From 2010 onward, additional community colleges have been set up in Lao Cai, Bac Kan, and Lai Chau. In addition, three community colleges have been merged and upgraded to local universities, including Quang Ngai Community College, Tien Giang Community College, and Tra Vinh Community College.

To date, apart from these three provinces, others have drafted or formulated the framework to upgrade community colleges to universities. The trend of upgrading community colleges to universities has becoming more and more evident. The key reasons that explain for this trend, on the one hand, lie in the difficulties and challenges in developing and operating community colleges and, on the other hand, the psychology of the leadership of the local province/city in wishing to put in place a provincial university as well as that of local residents in outweighing university degrees over college diplomas, which make it very difficult to attract students. Nevertheless, these reasons would gradually change with the improvement in awareness among local residents.

\section{Local Universities-A Type of Community Higher Educational Institution in Viet Nam}

In Viet Nam, educational institutions are subject to the dual administration: vertical sector and geographical location. When it comes to sector-wide administration, educational institutions are subject to the management of the respective sector, specifically the ministry under the central government. In terms of geographical location, the same educational institutions are subject to the management of the respective local government. 
Previously, in Viet Nam, there were only universities managed and operated by various ministries at the central level, not until recently were there universities set up in the province and owned by the provincial people's committee. Logically speaking, these are referred to as local universities.

Therefore, local universities are understood as the public-run universities managed and operated by the provincial government, mandated to provide trainings in response to the manpower demands for the sake of local socio-economic development. Key characteristics of local universities are as follows:

1. They are the universities managed by local (provincial) government;

2. Priority is given to serving the immediate manpower demands of the province in accordance with the direction and guidance of the provincial government. However, there are no regulations that hinder the accommodation of learning demands of other localities. These universities generate resources upon receipt of the provincial budget; the mobilisation of other resources is nothing different than other universities;

3. The training programmes are otherwise as diverse, multidisciplinary, and multilevel as that offered by community colleges except for the training at university level. There are universities that are currently even providing postgraduate training programmes (as is in the case of Hong Duc University and Thanh Hoa Province). Whether a local university provides training programmes of such a certain level depends solely on its capacity. There are no regulations that prevent a local university to provide postgraduate training programmes. Furthermore, these local universities also provide other educational and technology transfer activities to local residents, such as supplementary education programmes, short-term vocational trainings, refresh-trainings, and transfer trainings with a view to meet practical learning needs of local populations.

As such, local universities are set up under the direct management of the provincial government. They do not wish to limit their training programmes to collegiate level, which is initially intended for, and therefore have made efforts to upgrade the provincial college to the provincial university. In certain cases, the provincial government took the initiative to set up the provincial university from the onset. The first case was Thanh Hoa Province with the establishment of Hong Duc University. Thanh Hoa was the province in which a community college was initially intended to be set up and one of the provinces falling under the research project on the eligibility conditions to set up a community college therein on the basis of several locally owned colleges (under the auspices of the project financed by ADB in 1996). Thereafter, however, as the provincial government observed lots of favourable conditions (1997), it proceeded with setting up the local university: Hong Duc University. After 17 years of operations, Hong Duc University has to date provided Master's training programmes truly as a university.

As of late December 2014, Viet Nam had 24 local universities falling under the direct management and operation of the provincial government. They are evenly distributed throughout three regions: North, Middle, and South.

With respect to the mission and objective of local universities, because they cover the mission and objective of a community college, as a matter of fact, the functions and tasks of local universities cover that of a community college. Thus, the local university model is a type of the local higher education institution at the university level, which embodies functions of a community college.

In short, it can be seen that both community colleges and local universities are currently performing three overarching functions, as follows:

1. They offer multidisciplinary, multilevel and multiform training programmes in response to the demands of the local province for graduates of university qualifications or lower; 
2. They provide continuing education programmes that enable local residents to effectively balance their work and study, learn continuously throughout their life in order to round up their personality, expand understanding, and upgrade their educational qualifications for the ultimate goal of enhancing livelihoods, increasing job opportunities, and self-employment prospects, which help to improve the quality of life and skilfully adapt with social life, and then contribute to socialising education and building a learning society at the grassroots level;

3. They offer science and technology applications that serve the production and operational processes of local community.

Therefore, one of the key common functions of community colleges and local universities in Viet Nam is to meet local demands for manpower, mainly with university qualifications or lower. In comparison with other countries, the community of higher education institutions in Vie Nam have already provided graduate training programmes, even postgraduate programmes in certain localities.

\section{Community Colleges and Local Universities in Response to Local Manpower Demands}

To assess the role played by community colleges and local universities in Viet Nam in meeting manpower demands in the country, the research project has conducted a field survey in a number of community colleges and local universities in six provinces/municipalities across the country: the North, i.e., Ha Noi (Ha Noi Community College), Hai Phong (Hai Phong University and Hai Phong Community College); the Middle: Phu Yen (Phu Yen University); and the South: Tien Giang (Tien Giang University), Kien Giang (Kien Giang University and Kien Giang Community College), and Tra Vinh (Tra Vinh University). These provinces are home to both community colleges and local universities, or to local universities which were formerly community colleges.

The main method used in the research was both quantitative (i.e., questionnaires and statistical sheets) and qualitative in nature (i.e., in-depth interviews, focused group discussions, and expert consultations) with the following participants: representatives from the ministries/central agencies, such as the Ministry of Education and Training (MOET), the Ministry of Labor, Invalids, and Social Affairs (MOLISA), the National Assembly Committee for Culture, Education, Youth, Adolescents and Children, Government Office, Vietnam Association of Community Colleges (VACC), and Viet Nam Learning Promotion Association; local government representatives from six provinces/cities; Department of Education and Training (DOET) managers from six provinces/cities; representatives of Provincial Learning Promotion Association or University/College managers (Community Colleges, Local Universities, Vocational Colleges, and Upper Secondary Schools); lecturers, parents, and students. The quantitative data were then entered into Epidata software and processed through Statistical Processing for Social Studies (SPSS). On the other hand, qualitative data were collated and analysed by various parameters.

According to statistical data, local universities currently provide trainings at three levels, i.e., professional secondary college, university, and community colleges, on the other hand, they provide trainings at two levels, i.e., professional secondary and collegiate (see Figures $2-7)^{3}$.

As can be seen from Figures 2-7 that, generally speaking, the training capacity of both community colleges and local universities grew constantly until recently when the trend became quite slow, especially in the case of community colleges (with an exception of Phu Yen University). This situation can be explained by the fact that nowadays there are more and more universities that are set up, thus leading to more fierce

\footnotetext{
${ }^{3}$ Source: Survey findings of the research project, 2014.
} 
competition among them. Also, students and their parents usually prefer to study at central universities located in big cities, hence moving away from their home province to such cities to pursue their studies.

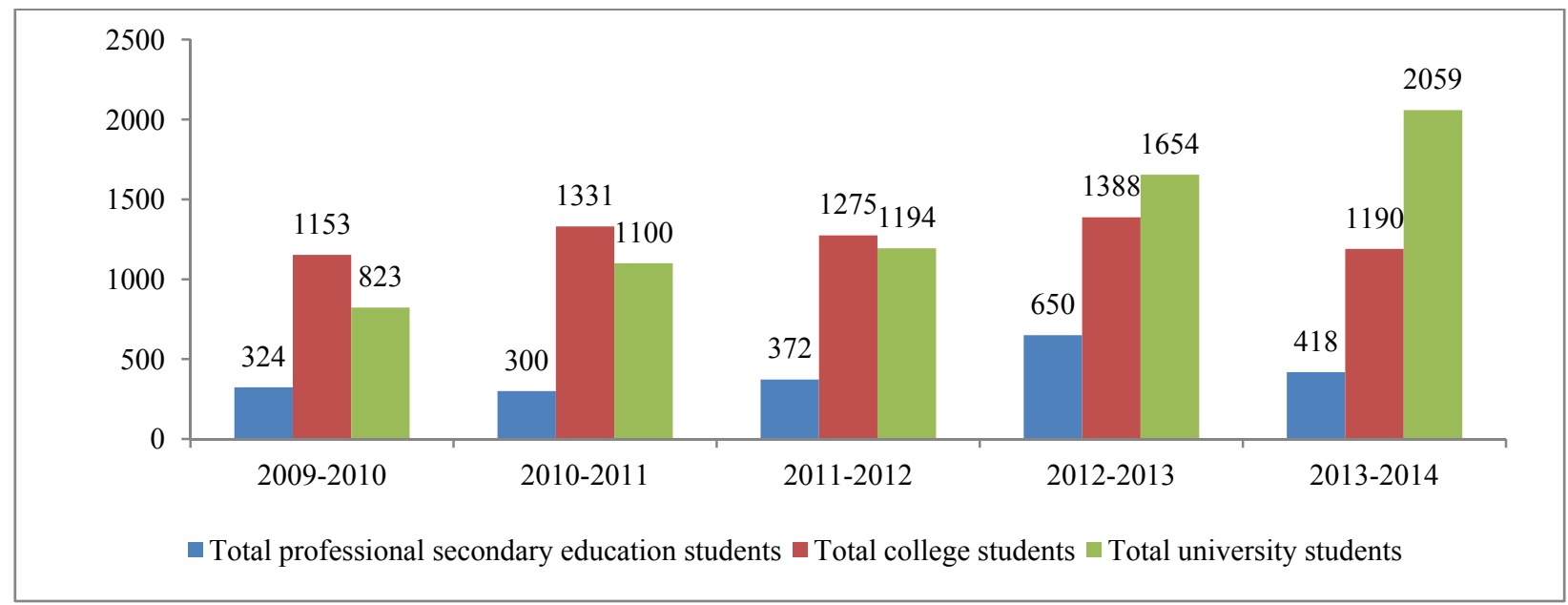

Figure2. Training capacity of Phu Yen University (2009-2014).

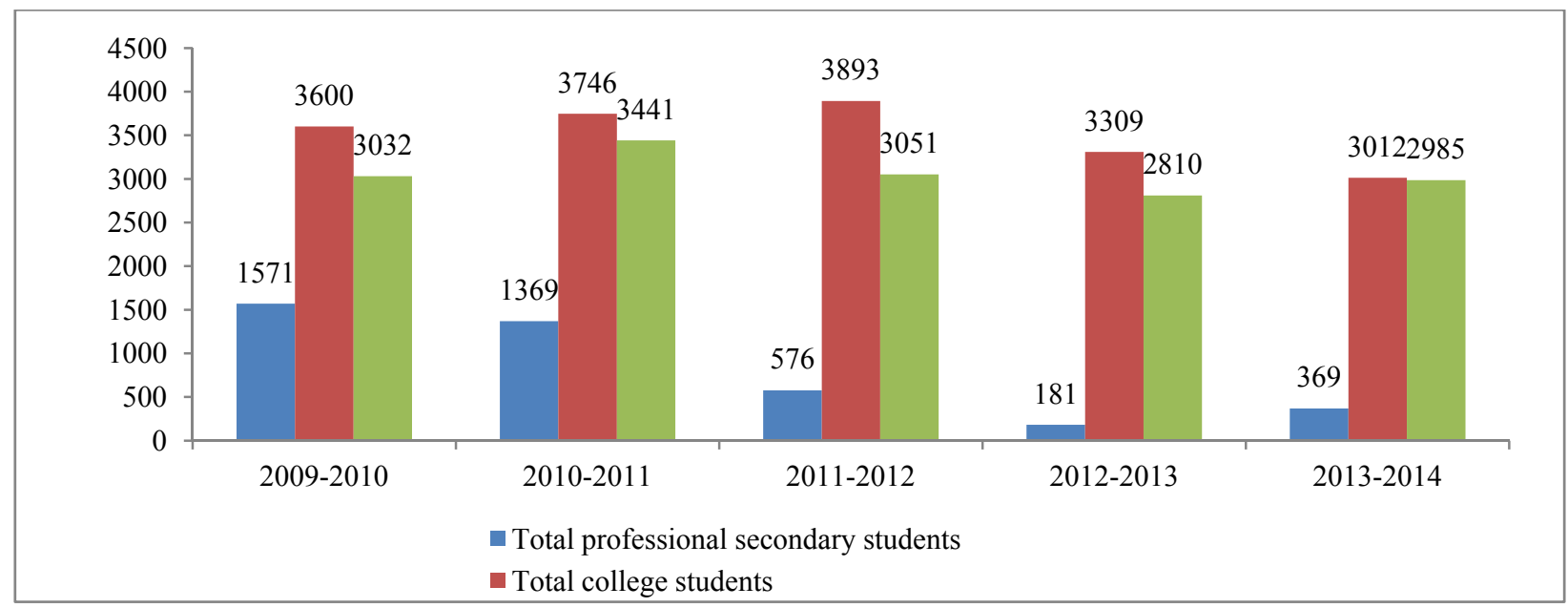

Figure 3. Training capacity of Tien Giang University (2009-2014).

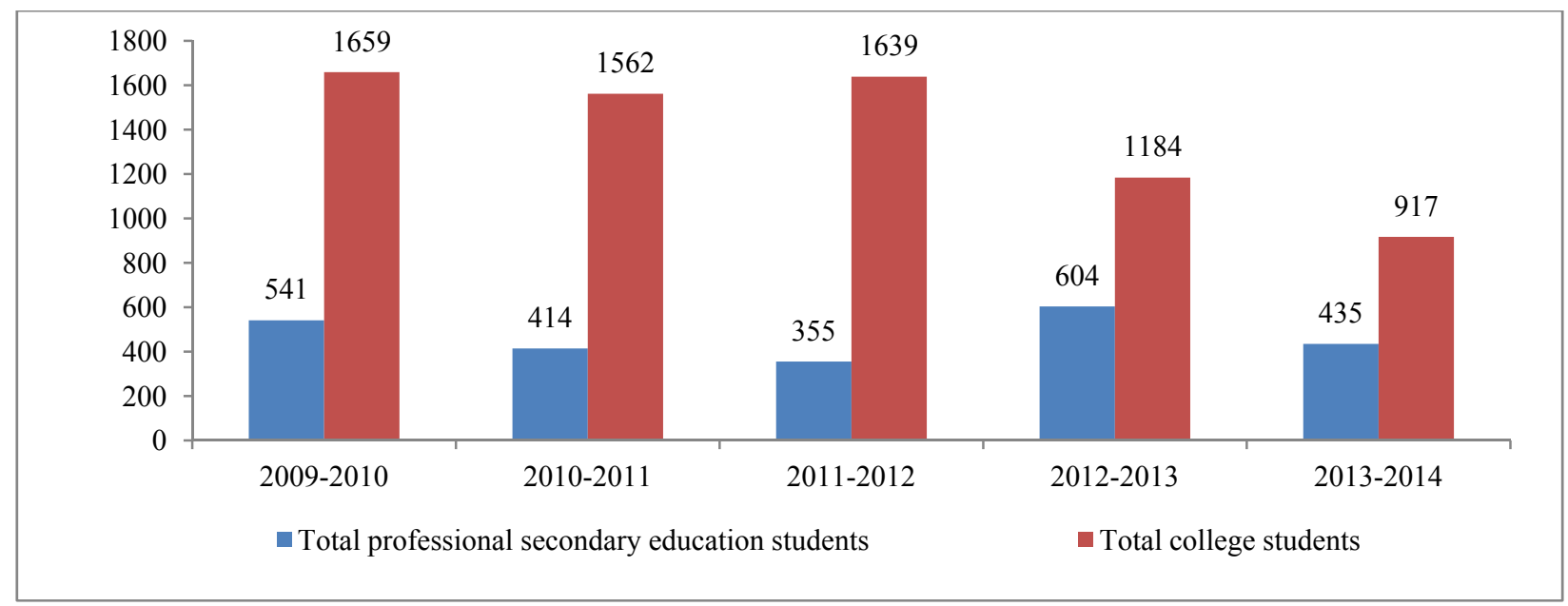

Figure 4. Training capacity of Kien Giang Community College(2009-2014). 


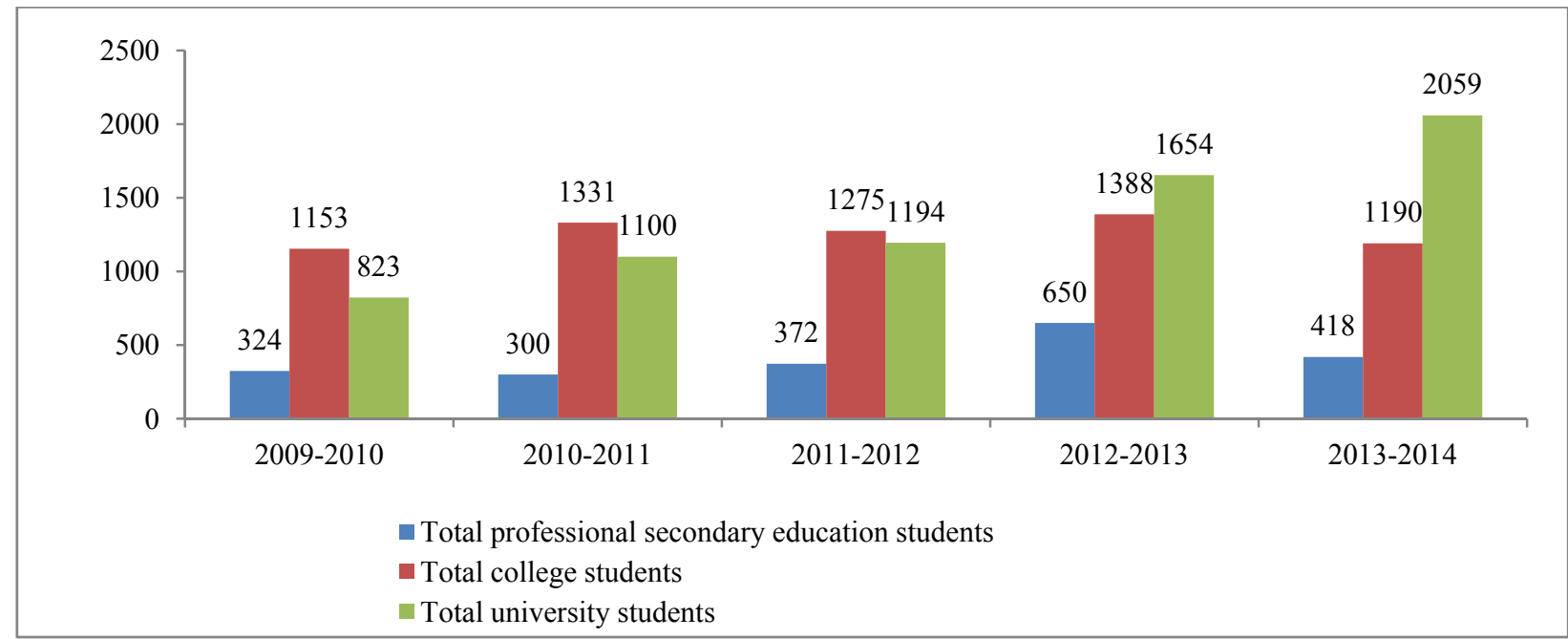

Figure 5. Training capacity of Tra Vinh University (2009-2014).

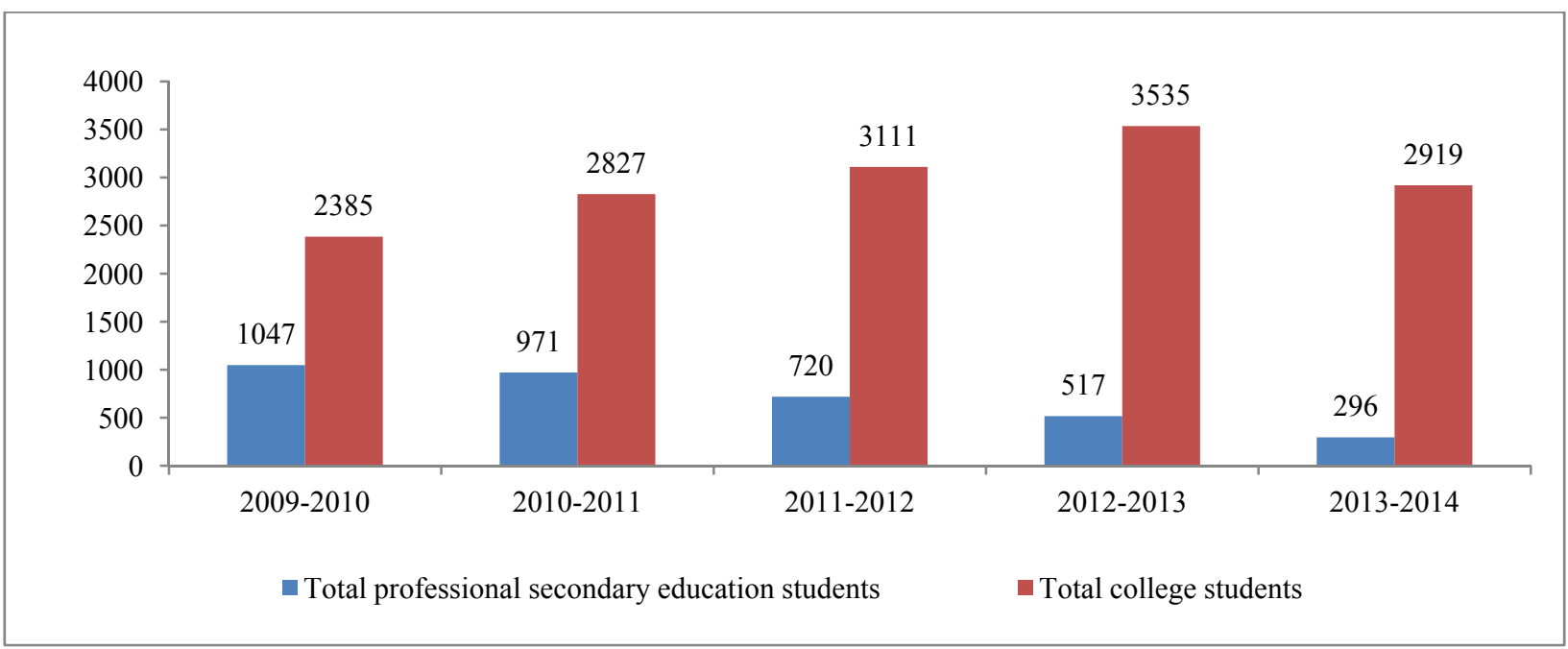

Figure 6. Training capacity of Ha Noi Community College (2009-2014).

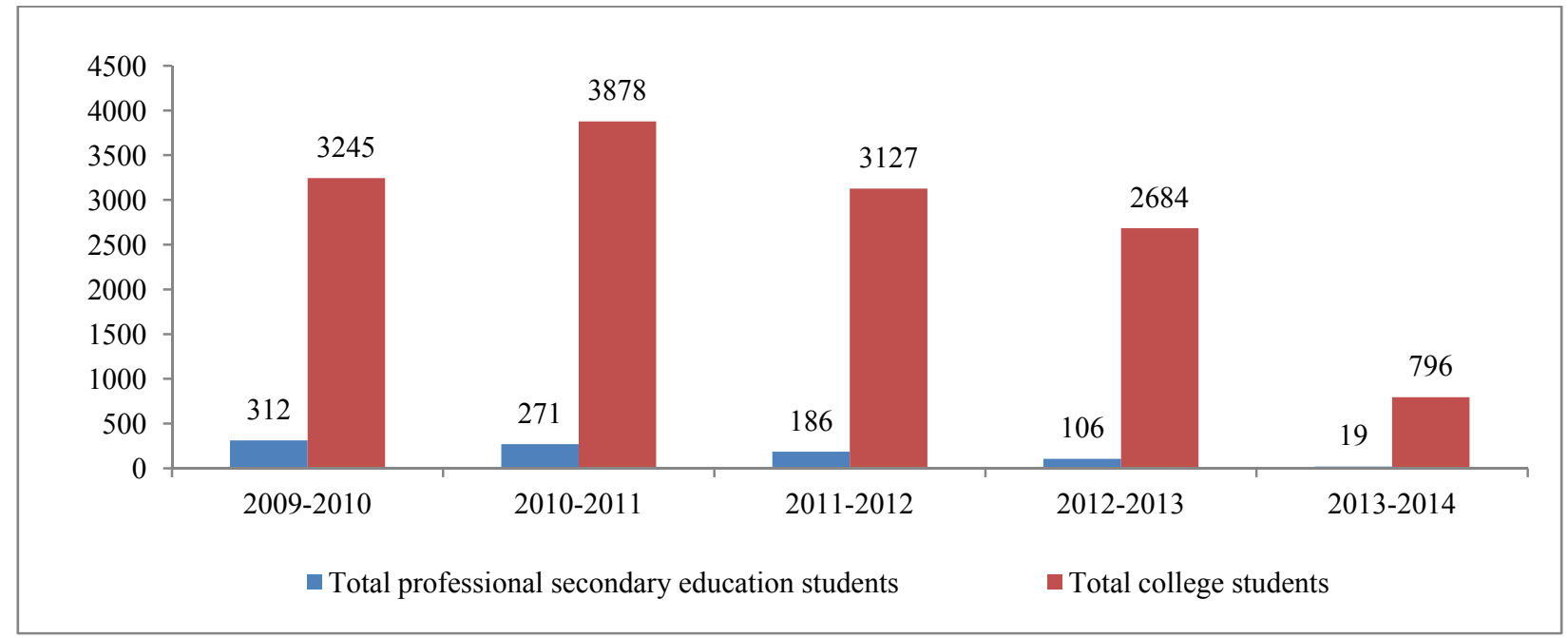

Figure 7. Training capacity of Hai Phong Community College (2009-2014). 
The survey findings also show that to satisfy the manpower demands for the sake of the local socio-economic development, community colleges and local universities have basically focused on practically-applied training programmes at university or college, or even lower level, contributing to the realisation of the mission in raising people's knowledge, training manpower, and nourishing talents for the whole country and the respective locality.

In addition, the survey findings also reveal that the percentage of graduates from both community colleges and local universities who can find jobs is relatively high. For example, in Tien Giang University, the percentage of graduates who can find jobs one year after graduation from the university-level programmes is in the range of $75 \%-89 \%$, and from college-level programmes is in the range of $70 \%-80 \%$. These rates for both Kiên Giang University and Kien Giang Community College are higher than $80 \%$. Several other provinces also share the same patterns (see Tables $3 \& 4$ ).

Table 3

Employment Status Among Graduates of Phu Yen University

\begin{tabular}{|c|c|c|c|c|c|c|c|c|c|c|c|}
\hline \multirow{2}{*}{$\begin{array}{l}\bar{D} \\
\stackrel{d}{\lrcorner}\end{array}$} & \multirow{2}{*}{ Form of training } & \multicolumn{5}{|c|}{ Percentage of graduates who can find jobs } & \multicolumn{5}{|c|}{$\begin{array}{l}\text { Percentage of graduates who can meet } \\
\text { local manpower demands }\end{array}$} \\
\hline & & $2009-2010$ & $2010-2011$ & 2011-2012 & $2012-2013$ & 2013-2014 & $2009-2010$ & $2010-2011$ & 2011-2012 & $2012-2013$ & 2013-2014 \\
\hline \multirow{3}{*}{ 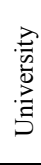 } & Formal & & $90 \%$ & $70 \%$ & $70 \%$ & $70 \%$ & & $60 \%$ & $60 \%$ & $60 \%$ & $60 \%$ \\
\hline & $\begin{array}{l}\text { Formal, college-university } \\
\text { articulation }\end{array}$ & $95 \%$ & $96 \%$ & $90 \%$ & $90 \%$ & $90 \%$ & $95 \%$ & $95 \%$ & $90 \%$ & $90 \%$ & $90 \%$ \\
\hline & $\begin{array}{l}\text { College-university articulation, } \\
\text { study-and-work combined }\end{array}$ & $98 \%$ & $98 \%$ & $98 \%$ & $98 \%$ & $97 \%$ & $95 \%$ & $98 \%$ & $98 \%$ & $98 \%$ & $97 \%$ \\
\hline \multirow{3}{*}{$\begin{array}{l}\stackrel{0}{\circ} \\
\frac{0}{\overline{0}} \\
\end{array}$} & Formal & $70 \%$ & $70 \%$ & $70 \%$ & $70 \%$ & $70 \%$ & $60 \%$ & $60 \%$ & $60 \%$ & $60 \%$ & $60 \%$ \\
\hline & $\begin{array}{l}\text { Formal, college-university } \\
\text { articulation }\end{array}$ & & $90 \%$ & $90 \%$ & $90 \%$ & $90 \%$ & & $90 \%$ & $90 \%$ & $90 \%$ & $90 \%$ \\
\hline & $\begin{array}{l}\text { College-university articulation, } \\
\text { study-and-work combined }\end{array}$ & $95 \%$ & $98 \%$ & $98 \%$ & $98 \%$ & & $95 \%$ & $98 \%$ & $98 \%$ & $98 \%$ & \\
\hline
\end{tabular}

Note. Survey findings of the research project, 2014.

A closer look at Ha Noi Community College also shows a positive trend (see Table 4).

Table 4

Employment Status of Graduates from Ha Noi Community College

\begin{tabular}{|c|c|c|c|}
\hline Academic year & Form of training & $\begin{array}{l}\text { Percentage of graduates } \\
\text { who can find jobs }\end{array}$ & $\begin{array}{l}\text { Percentage of graduates who can } \\
\text { meet local manpower demands }\end{array}$ \\
\hline & Formal & $99 \%$ & $96 \%$ \\
\hline $2009-2010$ & $\begin{array}{l}\text { Formal, secondary- college articulation } \\
\text { Total }\end{array}$ & $99 \%$ & $90 \%$ \\
\hline & Formal & $61.80 \%$ & $80 \%$ \\
\hline $2010-2011$ & $\begin{array}{l}\text { Formal, secondary- college articulation } \\
\text { Total }\end{array}$ & $62 \%$ & $78 \%$ \\
\hline 2011-2012 & $\begin{array}{l}\text { Formal } \\
\text { Formal, secondary- college articulation } \\
\text { Total }\end{array}$ & $73.40 \%$ & $82 \%$ \\
\hline $2012-2013$ & $\begin{array}{l}\text { Formal } \\
\text { Formal, secondary- college articulation } \\
\text { Total }\end{array}$ & $69 \%$ & $96.60 \%$ \\
\hline $2013-2014$ & $\begin{array}{l}\text { Formal } \\
\text { Formal, secondary- college articulation } \\
\text { Total }\end{array}$ & $65 \%$ & $92 \%$ \\
\hline
\end{tabular}

Note. Survey findings of the research project, 2014. 
Table 3 and Table 4 reveal a positive trend about training results of both community colleges and local universities. To ensure a high degree of reliability of these data, it is necessary to conduct systematic graduate tracer study to allow for more accurate time-series information.

The in-depth interview findings indicate that there is generally a high degree of socialisation among both community colleges and local universities, because they are closely linked with local businesses and recruiters; their training programmes offered are based on the investigation of practical learning needs, so that their training products can easily meet such manpower requirements.

In the capacity as a university branch, our campus has satisfied the task assigned to us and also met the manpower demands of the home province. For example, in the fisheries and fish processing, our training products have satisfied practical demands of the province. Graduates can meet manpower requirements of both home and neighbouring provinces. Even in some training specialisations, the number of graduates does not meet the practical manpower demands. (An excerpt from the interview with a representative of Kien Giang University)

On an annual basis, Kien Giang University and Kien Giang Community College conduct a field survey to capture learning needs across the province to ensure that the training disciplines and specialisations are well in line with the province's manpower demands. For example, fish farming and fishery processing are growing rapidly in the province; both Kien Giang University and Kien Giang Community College have focused on these specialisations in their training programmes. It is understood that Kien Giang University and Kien Giang Community College have effectively met the home province's manpower demands. (An excerpt from the interview with a representative Provincial People's Committee)

The percentage of graduates from Kien Giang Community College who can find jobs with six months is well above $80 \%$, which is a reflection of the strong effort made by our college. We set up a strong relationship with local businesses, the owners of which are usually college alumni and therefore create favourable conditions in terms of practicum venues and career guidance for current students. It is also with the help of such businesses that we come to know the manpower demands of the local labour market based on which to adjust training programmes. Changes to training programmes are made as frequently as three years in order to meet practical manpower demands of the local province. (An excerpt from the interview with a Board representative of Kien Giang Community College) (Source: Survey findings of the research project in Kien Giang University, 2014)

Our University frequently offers short-term training courses in order to meet the immediate manpower demands for the sake of socio-economic development and production management. These courses are aimed to upgrade professional knowledge and practical skills for farmers, workers; and strengthen English language and IT skills for civil servants.

In most cases, training fields are well in line with local manpower demands. The core training fields offered by our university include Primary Education, ECED, Fishery Processing Technology, and Biotechnology. For training programmes specialising in Agricultural Engineering, Civil Engineering, Information Technology, Mechanics, Rural Development, Veterinary and Automatic Technology, there are very few students enrolled.

On 10-year average, the percentage of graduates for can find jobs is $74 \%$, and the percentage of those who can find suitable jobs with what they have been trained is well above $50 \%$.

A majority of civil servants from grassroots level to provincial departments are training products of our university. This is also true of managers, technicians and highly-skilled workers working across the province.

Nevertheless, in our province, there are quite a number of enterprises that employ low-skilled workers, therefore a portion of graduates from our university tend to look for jobs in Ho Chi Minh City and provinces in the Southeast Region. (An excerpt from the interview with a representative of Tien Giang University) (Source: Survey findings of the research project in Tien Giang University, 2014)

The Board of Management develops the strategic plan for university development, opens up the close link between the university and the home province, using specific partnership models, e.g., university-business partnership. This partnership has helped our university operate effectively.

We work very closely with local businesses. This has been of significant importance to the university in a sense that we know the training demands. Businesses are also involved in our training process; they act as the member of the university advisory panel, which is a great asset for students to practice their skills and find jobs right in such businesses...

We also offer training programmes that link the practicum among students with businesses. This model is quite successfully and implemented in Tra Vinh University. 
Finally, we provide short-term training programmes, which involve local artisan and other practitioners to train students. (An excerpt from the interview with a Board representative of Tra Vinh University) (Source: Survey findings of the research project in Tra Vinh University, 2014)

Apart from the community colleges and local universities that obtain positive results in the course of their operations, there are others that have difficulties in not only the student admission, but also the destination for graduates.

There are many training areas and specialisations offered by our university. However, there are little demands from the province. In addition, the demands from society are phase-based, but the university keeps its lines of operations without any change. Therefore, it can easily understand that there are a big number of graduates from the university who cannot find jobs. The provincial leadership has no control over the training quota for the university. (An excerpt from the interview with the Faculty's officer, Hai Phong University)

In some other fields, such as the social work, they only recruit applicants with at least three to five years of work experience. Therefore, fresh graduates from the university can't find jobs right away because of their lack of practical experience. (An excerpt from the interview with faculty member, Hai Phong University) (Source: Survey findings of the research project in Hai Phong University, 2014)

In the case of Phu Yen University, this is a local university that provides multidisciplinary and multilevel training programmes. Initially, it only admitted students within Phu Yen Province but since 2009, it has expanded the admission scope to include all students from throughout the country. Teacher education is the key strength of the university. The provincial Department of Education and Training has highly appreciated the training activities implemented by the university. The training disciplines currently offered by the university can meet the province's manpower demands in such fields as economics, agriculture, foreign languages, informatics, and especially teacher workforce. Nevertheless, the province has not used up the manpower supplied by the university because of the unbalanced local economic development, especially in the education sector which can no longer absorb additional teachers. The Department of Education and Training is currently keeping a stockpile of thousands of applications from applicants who wish to become a teacher. These applicants are actually graduates from many different institutions across the country, not necessarily from Phu Yen University. This is a very difficult situation for DOET and for Phu Yen University alike.

Although Phu Yen University is on its surface a multidisciplinary and multilevel training institution, the number of training disciplines and specialisations is indeed very small, hence unable to meet local diverse manpower demands. For example, the training capacity of Phu Yen University in technology-related specialisations is very limited. (An excerpt from the interview with a representative of Phu Yen DOET)

The poor ability to meet local manpower demands among local universities and community colleges has also been echoed by representatives of central management agencies.

Generally, there is not yet a close connection made between training and local manpower demands. The student admission is largely based on arbitrary preferences of learners without taking into consideration the actual dynamics of local labour market. Therefore, these institutions are not yet able to meet local manpower demands.

The number of training disciplines and specialisations that are suitable with local labour characteristics is quite small. In this regard, there is no significant difference between local universities and central universities.

There is a serious concern over the ability to find jobs upon graduation; labour is redundant in some fields but lacking in others; training quality is low. (An excerpt from the interview with a MOET representative) (Source: Survey findings of the research project, 2014)

It can be seen from the survey findings that, the ability to meet local manpower demands has a lot to do with the relevance and practicality of training disciplines and specialisations offered by local universities and community colleges with local socio-economic development characteristics. This is what local universities and community colleges should bear in mind when opening training disciplines and specialisations if they are to ensure a good match between training and labour market demands. 
Overall, however, the survey findings show that most respondents keep positive views on the ability to meet local manpower demands among community colleges and local universities.

The training activities of community colleges and local universities have resulted a significant number graduates with college and university qualifications, which in turn brings about a diverse pool of manpower for recruitment, selection and deployment across the spectrum of industries and occupations. (An excerpt from the interview with a MOET representative)

With regard to the missions of local universities or community colleges/universities, it is of the DOET's opinion that they bear very important missions. If local universities or colleges are strong enough, they can both effectively meet local diverse manpower demands and conduct science research to serve the interests of local community. (An excerpt from the interview with a leader of Phu Yen DOET) (Source: Survey findings of the research project, 2014)

The foregoing are positive viewpoints for community colleges and local universities for the socio-economic benefits of the existence of these types of local higher education institutions.

\section{Conclusions}

Increasingly, community colleges and local universities are promoting their roles as centres for culture, education, science and technology, and community development across provinces. The model of community college and local university is considered one of the optimal solutions to manpower training in provinces in response to socio-economic development in Viet Nam. The establishment and development of these higher education institutions are grounded on the idea of developing higher education for all—an indispensable trend occurring in various countries in the era of international integration and economic globalization.

With a combination of professional and vocational education, long-term and short-term training courses, flexible and well-articulated training procedure, and the application of both conventional and the multi-phase training models, these institutions have made important contributions to increasing learning opportunities and stratifying manpower quality in Viet Nam.

Training programmes provided by community colleges and local universities are geared more toward professional training than academic knowledge. Therefore, they serve as a strong bridge between general education and labour market, helping students acquire foundational skills to move from the training institution to the workplace in the most possible appropriate manner.

In order to promote the strengths of community colleges and local universities in Viet Nam, it is suggested that various sectors and administrative levels should create favourable conditions in all facets, so that these institutions can develop rapidly and sustainably in terms of physical infrastructure, equipment, as well as the size and quality of training. In addition, it is imperative that the institutions themselves put in place development strategies with resultant investments into staff development and instructional enhancement, and take care of training contents, methods, and modalities that are suitable with local manpower demands. Doing so will help them more effectively realize their missions of supplying manpower for the sake of local socio-economic development and better justify their existence and growth.

\section{References}

Dang, B. L. (2016). Survey findings of the research project VI2.3-2012.13: Developing and applying the model of community college and local university in Viet Nam in response to local manpower demands in the context of industrialisation and international integration. Vietnamese: Project VI2.3-2012.13's Document.

Dang, B. L., \& Nguyen, H. V. (2009). The development of the community college model in Vietnam at the time of the country's reorganization and international integration (Chapter 7). In Community college models-globalization and higher education reform. Berlin: Springer. 
Dang, B. L. (1996). Setting-up a community college model in the Vietnamese socio-economic setting: Case studies in education research and policy. Mandaluyong: ADB.

General Statistics Office. (2013). Viet Nam labour force and employment survey report. Vietnamese: General Statistics Office Publishing.

Institute of Labour Science and Social Affairs. (2013). Labour and social trends in the context of recession of economic growth. Vietnamese: Cuu Long University. Retrieved September 10, 2014, from http://mku.edu.vn/khoacntt/index.php/tin-t-c/71sach-tr-ng-bao-d-ng-d-v-nhan-l-c-vi-t-nam

Nguyen, H. V. (2009). Developing a community college model in response to local socio-economic development requirements in Viet Nam (Doctoral dissertation, Hanoi National University, 2009).

Nguyen, H. V. (2011). Community college model in Viet Nam. Ha Noi: Dan Tri Publishing House.

The Communist Party of Vietnam. (1961). The resolution of 3rd national congress. Vietnamese: National Political.

The Communist Party of Vietnam. (1991). The resolution of 6th national congress. Vietnamese: National Political.

World Bank. (2008). Vietnam - Higher education and skills for growth (English). Ha Noi: WB Publishing. 